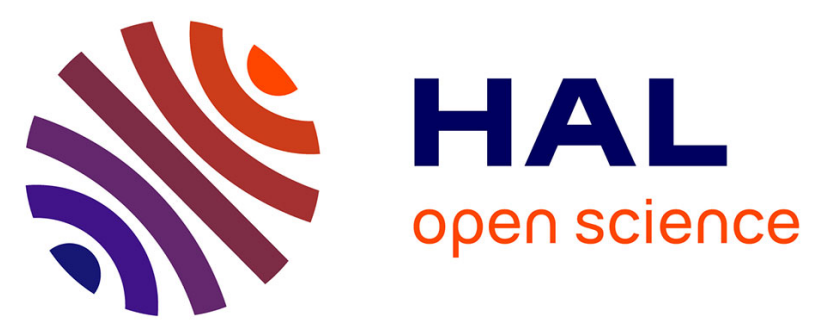

\title{
Climate variability of the last 2700 years in the Southern Adriatic Sea: Coccolithophore evidences
}

Antonio Cascella, Sergio Bonomo, Bassem Jalali, Marie-Alexandrine Sicre, Nicola Pelosi, Sabine Schmidt, Fabrizio Lirer

\section{- To cite this version:}

Antonio Cascella, Sergio Bonomo, Bassem Jalali, Marie-Alexandrine Sicre, Nicola Pelosi, et al.. Climate variability of the last 2700 years in the Southern Adriatic Sea: Coccolithophore evidences. The Holocene, 2019, 30 (1), pp.53-64. 10.1177/0959683619865600 . hal-02189322

\section{HAL Id: hal-02189322 \\ https://hal.science/hal-02189322}

Submitted on 21 Jul 2019

HAL is a multi-disciplinary open access archive for the deposit and dissemination of scientific research documents, whether they are published or not. The documents may come from teaching and research institutions in France or abroad, or from public or private research centers.
L'archive ouverte pluridisciplinaire HAL, est destinée au dépôt et à la diffusion de documents scientifiques de niveau recherche, publiés ou non, émanant des établissements d'enseignement et de recherche français ou étrangers, des laboratoires publics ou privés. 
This is the peer reviewed version of the following article: [Antonio Cascella, Sergio Bonomo, Bassem Jalali, Marie-Alexandrine Sicre, Nicola Pelosi, Sabine Schmidt, Fabrizio Lirer (2019). Climate variability of the last 2700 years in the Southern Adriatic Sea: Coccolithophore evidences. The Holocene, which has been published in final form at [doi.org/10.1177/0959683619865]. This article may be used for non-commercial purposes in accordance with SAGE Terms and Conditions for Self-Archiving. 
2 Climate variability of the last $\sim 2700$ years in the Southern Adriatic Sea:

\section{Coccolithophore evidences}

4

5 Antonio Cascella ${ }^{{ }^{*}}$, Sergio Bonomo ${ }^{1-2-3}$, Bassem Jalali ${ }^{4}$, Marie-Alexandrine Sicre ${ }^{4}$, Nicola Pelosi ${ }^{2}$,

6 Sabine Schmidt ${ }^{5}$, Fabrizio Lirer ${ }^{2}$

7 1) Istituto Nazionale di Geofisica e Vulcanologia (INGV), Via della Faggiola 32, 52126, Pisa;*

8 corresponding author: antonio.cascella@ingv.it

9 2) Istituto di Scienze Marine (ISMAR), Consiglio Nazionale delle Ricerche (CNR), Calata Porta di

10 Massa, Interno Porto di Napoli, 80133- Naples, Italy.

11 3) Istituto di Biomedicina ed Immunologia Molecolare "Alberto Monroy" (IBIM), Consiglio

12 Nazionale delle Ricerche, Via Ugo La Malfa 153, 90146, Palermo, Italy;

13 4) Sorbonne Universités (UPMC, Univ. Paris 06) CNRS-IRD-MNHN, LOCEAN Laboratory, 4 place 14 Jussieu, F-75005 Paris, France;

15 5) UMR5805 EPOC, Université de Bordeaux, Avenue Geoffroy Saint-Hilaire, 33615 Pessac, France; 


\section{Abstract}

New information on paleoenvironmental conditions over the past $\sim 2700$ years in the Central

Mediterranean Sea have been acquired through the high-resolution study of calcareous nannofossils preserved in the sediment core SW104ND14Q recovered in the Southern Adriatic Sea (SAS) at 1013 m water depth. The surface water properties at this open SAS site are sensitive to atmospheric forcing (acting both at local and regional scale) and the North Ionian Sea driven inflowing waters. Our data show a relationship between reworked coccolith abundances, flood frequency across the Southern Alps and the North Atlantic Oscillation (NAO) confirming their value as indicator of runoff/precipitation. Changes in the abundance of the opportunistic (r-strategist) species Emiliania huxleyi and deep dweller taxa Florisphaera profunda were used to reconstruct the upper water column stratification and associated changes in coccolithophorid productivity. The negative correlation between reworked coccoliths and the N-Ratio $\left(\mathrm{r}=-0.44 ; p=6^{-7}\right)$ suggest that fresh water induced stratification is a controlling factor of the SAS coccolithophorid production. High coccolithophorid productivity levels occurred during dry periods and/or time intervals of inflowing salty and nutrient-rich Levantine Intermediate Waters (LIW) favouring convection while lower levels took place during high freshwater discharge, mainly during the Little Ice Age (LIA) and two centennial scale intervals of weakest NAO around 200 BCE and500 CE.

\section{Keywords}

38 Coccolithophores; reworked coccoliths; coccolithophorid primary productivity; South 39 Adriatic Sea; central Mediterranean; last millennia. 


\section{Introduction}

Coccolithophores (calcareous nannoplankton) and their fossil remains (calcareous nannofossils) are valuable source of information for paleoclimatic studies (Baumann et al., 2005). Coccolithophores are single cell calcareous algae whose ecology and vital functions are driven by environmental parameters within the ocean euphotic zone (e.g., temperature, salinity, sunlight, and nutrient supply). Therefore, abundances of selected taxa have been used to reconstruct variations of physical and environmental parameters and their relation with climate change and human activity. Their skeletons composed of tiny calcareous platelets (coccoliths) are highly abundant in marine sediments making them ideal fossils to produce high-resolution time series (Baumann et al., 2005). These microorganisms are usually considered to prefer warm, stratified, oligotrophic waters of low and middle latitude regions (e.g., Honjo and Okada, 1974; Ziveri et al., 2004). However, local oceanic features such as coastal currents, gyres, eddies, upwelling, and river runoff are known to regionally affect their productivity (Guerreiro et al., 2013). In addition, reworked coccoliths (i.e., the nannofossils which have been removed from their original sedimentary layer and redeposited in a younger layer) can provide information on sediment transport (Bonomo et al., 2014; Ferreira et al., 2008; Ferreira and Cachão, 2005) and used to reconstruct regional scale runoff and/or precipitation changes (Bonomo et al., 2016a; Incarbona et al., 2010; Sprovieri et al., 2006).

Understanding the trends and variability of the Mediterranean climate at local and regional scales has been subject of intense research. (Bonomo et al., 2016a; Cacho et al., 1999; Frigola et al., 2007; Martrat et al., 2004; Pérez-Folgado et al., 2004; Rodrigo-Gámiz et al., 2011; Rohling et al., 2002, 2015; Sbaffi et al., 2001; Sierro et al., 2005; Sprovieri et al., 2003, 2006; Triantaphyllou et al., 2009, 2016a). Shelf sediments of the Adriatic Sea (AS) provide ideal natural archives for high-resolution paleoclimatic investigations because of expanded Holocene sedimentary sequences and possible use of recurrent tephras for geochronological 
control (Jalali et al., 2018; Lowe et al., 2007; Marchini et al., 2014; Matthews et al., 2015;

Siani et al., 2013). Terrestrial and marine paleoclimate proxy data (e.g., calcareous plankton, lipid biomarkers, palynomorphs, stable isotopes, lake levels, and speleothems) have shown the occurrence of abrupt climate changes during the Holocene (warmer/colder and drier/wetter periods) at decadal, centennial to millennial time scales in the Mediterranean basin (e.g., Bini et al., 2019; Cisneros et al., 2016; Di Bella et al., 2014; Gogou et al., 2016; Goudeau et al., 2015; Grauel et al., 2013; Jalali et al., 2016, 2018; Kouli et al., 2012; Lirer et al., 2013, 2014; Margaritelli et al., 2016, 2018; Piva et al., 2008; Sicre et al., 2016; Skampa et al., 2019; Triantaphyllou et al., 2009, 2010, 2016b).

Many studies have focussed on (late) Holocene climate variability and its impact on the environment and human activity in the SAS (Caroli and Caldara, 2007; Combourieu-Nebout et al., 2013; Di Rita and Magri, 2009; Giunta et al., 2003; Grauel and Bernasconi, 2010; Jalali et al., 2018; Leider et al., 2010; Oldfield et al., 2003; Piva et al., 2008; Sangiorgi et al., 2003; Siani et al., 2013; Sicre et al., 2016). The recent study of Jalali et al. (2018) in the SAS highlighted the links between the centennial scale variability of SSTs and local climatic and oceanographic features, and notably the role of the Bimodal Oscillating System (BiOS) of the Ionian Sea and North Atlantic Oscillation (NAO). Although there has been a substantial number of publications on the investigated area, very few studies have explored calcareous nannofossils as a proxy of past climate and environmental changes (e.g., Giunta et al., 2003; Narciso et al., 2012; Sangiorgi et al., 2003). Narciso et al. (2012) studied a gravity core close to our site between 13000 and $5500 \mathrm{BP}$, thus focused on the Greenland Stadial 1/Younger Dryas, Pre-Boreal, and Sapropel 1 equivalent periods. Giunta et al. (2003) and Sangiorgi et al. (2003) reported data from 18000 to $2300 \mathrm{yrs}$ BP at a more southern site, documenting the distribution of calcareous nannofossils during the Sapropel S1. As far as living coccolithophores are concerned, the only study carried out in the SAS is that of Balestra et al. (2008) describing assemblages in the water column and surface coastal sediments of the Gulf 
of Manfredonia (SAS). Other very recent data were restricted to the Mid and North Adriatic Sea (e.g., Cerino et al., 2017; Godrijan et al., 2018; Skejić et al., 2018, and references there in) or are part of phytoplankton biomass and productivity assessments aiming at providing rough estimates of coccolithophore distribution in open SAS (e.g., Fonda Umani, 1996; Ljubimir et al., 2017, and references therein).

The aim of this work is to evaluate the reliability of Coccolithophores/calcareous nannofossils as a proxy of environment and climate variability over the last three millennia in the Central Mediterranean. For this purpose, we carried out a high-resolution study from a deep-sea gravity core recovered in the SAS and from a second shallow coastal gravity core (C5 Composite) from the Tyrrhenian Sea (Gulf of Gaeta) obtained within the framework of the NEXTDATA Project (http://www.nextdataproject.it). Our data evidence major changes in nutricline depth as well as variations of river runoff and precipitation. We explore the cause of the observed changes by comparing our results to alkenone derived Sea Surface Temperatures (SSTs) and terrestrial inputs derived from higher plant biomarkers (Jalali et al., 2018). We also use other indicators of past precipitation changes in the Mediterranean basin: i.e. the flood activity in the Southern Alps (Wirth et al., 2013), the reworked coccolith record from a Southern Tyrrhenian sea core (Bonomo et al., 2016b), the XRF record from lake sediments of the Iberian Peninsula (Moreno et al., 2012) and the reconstruction of the forested fraction of usable land in Central and Western Europe (Kaplan et al., 2009).

\section{Oceanographic setting of the study area}

The AS is a semi-enclosed basin located between the Italian Peninsula and the Balkans, connected to the Mediterranean Sea through the Strait of Otranto (Fig.1a). The North Adriatic (NA) is primarily influenced by the southeast Europe climate, while the SAS experiences more arid conditions typical of Mediterranean and Northern Africa climates (Ilijanić et al., 2014). The general surface circulation of the AS is cyclonic (Fig.1b,c) (Sellschopp and 
Álvarez, 2003) and consists of a northward current flowing along the eastern Adriatic coast

120 (i.e., the Eastern Adriatic Current, EAC) balanced by southward current flowing along the

121 western coast (i.e., the Western Adriatic Current, WAC). The intermediate layer mainly

122 present in the southern and mid AS is occupied by the Levantine Intermediate Water (LIW)

123 (Artegiani et al., 1997). The deep circulation is characterized by the Adriatic Deep Water

124 (ADW) a dense water mass formed by the mixing of the Northern Adriatic Dense Water

125 (NADW) and Southern Adriatic Dense Water (SADW) (Manca et al., 2002).

126 The SAS is a sub-basin (South Adriatic Pit, SAP, $1260 \mathrm{~m}$ max depth) characterized by a quasi-permanent cyclonic circulation, i.e. the South Adriatic Gyre (SAG; Gačić et al., 1997) (Fig. 1b,c). The physical and chemical properties of SAS surface waters depend on the characteristics of inflowing waters into the basin, the strength of SAG, as well as wind stress and river discharges. Inflowing waters consist mainly of WAC and NADW from the North, the LIW and occasionally Modified Atlantic Water (MAW) from the South. The WAC is strongly influenced by river runoff mostly from the Po River, making it fresher and nutrient rich. The inflow of LIW and MAW depends on the variability of the North Ionian Gyre (NIG) (Fig. 1b,c). According to the BiOS (Bimodal Oscillating System) model, the NIG circulation may either be cyclonic or anticyclonic (Civitarese et al., 2010; Gacic et al., 2010). This mechanism is sustained by internal processes driven by the density of the ADW outflowing the Otranto Strait. When the circulation in the NIG is cyclonic, saltier and warmer LIW enters the SAS promoting deep convection and the formation of a denser ADW. In an anticyclonic

139 NIG mode, fresher and colder MAW enters the SAS leading to the production of lower 140 density ADW. However, some studies invoke the role of more complex driving mechanisms 141 involving the whole Ionian Sea circulation and not just its northern sector (Reale et al., 2016;

142 Simoncelli et al., 2016; Theocharis et al., 2014). The intensity of the SAG depends on local 143 wind intensity and properties of advected waters from the Ionian Sea (Shabrang et al., 2016). 144 Shabrang et al. (2016) reported a significant negative correlation between the NAO index and 
146 and SAG variability because of additional effects of the advection of the Ionian waters,

147 suggesting that the BiOS mode does not depend on NAO. Nevertheless, Pinardi et al. (2015)

148 reported a sustained BiOS anticyclonic circulation during the period of positive NAO in $149 \quad 1987-1996$.

150 The surface waters of the SAS are more oligotrophic than those of the NA (e.g., Civitarese et 151 al., 1998). The influence of Po River and secondary Apennines rivers flowing into the western 152 AS on the nutrient budget of the SAS seems rather weak and limited to a narrow coastal 153 current flowing over the Italian shelf (Faganeli et al., 1989). The nutrient supply to the SAS 154 occurs mainly via the inflow of LIW lying at about $300 \mathrm{~m}$ in the Adriatic Sea (Gačić et al., 155 2002). Nevertheless, according to Civitarese et al. (2010) larger amounts of nutrients are 156 advected by the MAW during periods of anticyclonic BIOS.
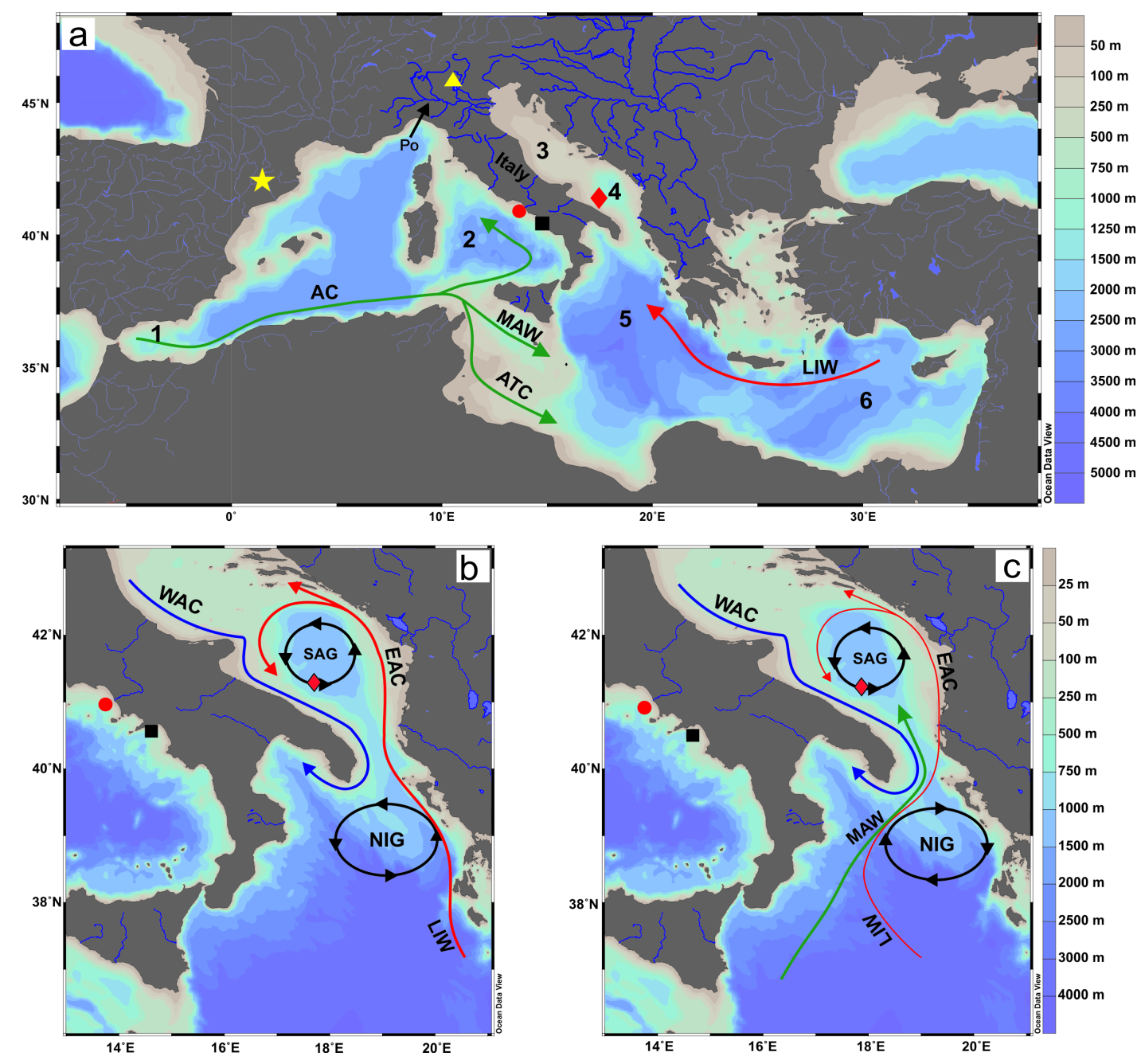
Figure 1. Location of the cores SW104-ND14Q (diamond), C5 Composite (dot), C90 (square,

159 Lirer et al., 2013), Basa de la Mora (star, Moreno et al., 2012), and Ledro (triangle, Wirth et

160 al., 2013). (a): bathymetric map of the Mediterranean Basin and main surface (green arrow)

161 and intermediate circulation pattern (red arrow). AC: Algerian Current; MAW: Modified

162 Atlantic Water ; ATC: Atlantic Tunisian Current; LIW: Levantine Intermediate Water.

163 Numbers 1-6: 1-Alboran Sea; 2-Tyrrhenian Sea; 3-Adriatic Sea; 4-South Adriatic Pit, SAP; 5-

164 Ionian Sea; 6 Levantine Sea. The main catchment basins of river flowing into the Adriatic Sea

165 are reported (blue thick lines). (b) and (c): bathymetric map and main circulation pattern of

166 South Adriatic Sea and North Ionian Sea during cyclonic (b) and anticyclonic (c) mode of the

167 BiOS; WAC: Western Adriatic Current; EAC: Eastern Adriatic Water; LIW: Levantine

168 Intermediate Water; MAW: Modified Atlantic Water; SAG: South Adriatic Gyre; NIG: North

169 Ionian Gyre.

170

\section{Methods}

172 Core SW104-ND14Q

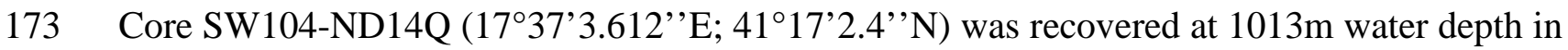

174 the SAS (Fig. 1). The sedimentary sequence was retrieved with a SW104 gravity corer

175 system, which preserves the water-sediment interface and allowed the recovery of $116 \mathrm{~cm}$ of

176 undisturbed and uncompressed homogeneous brown-grey hemipelagic sediments. The

177 magnetic susceptibility measured on board with a Bartington Instrument M2 revealed three

178 tephra layers (Fig. 2). The age model used here is from Jalali et al. (2018) and has been

179 constructed combining radionuclides ages $\left({ }^{210} \mathrm{~Pb}\right.$ activity-depth profile and ${ }^{137} \mathrm{Cs}$ activity) for

180 the last ca. 150 years and the additional dates derived from the correlation of three tephra

181 layers with well-dated volcanic events onland [Pompei eruption (79 CE); Pollena eruption

182 (472 CE); 1631 CE] (see Jalali et al. 2018 for details on tefrostratigraphy). Linear

183 interpolation between the tie-points has been used to construct the age-depth profile from the

184 top down to the base core documenting a mean Sed. Rate of $0.04 \mathrm{~cm} / \mathrm{y}$ (Fig. 2). Based on the

185 age model, core SW104-ND14Q ranges from $700 \mathrm{BCE}$ to $2003 \mathrm{CE}$ and has a mean temporal

186 resolution of $\sim 26 \mathrm{yrs}$. 


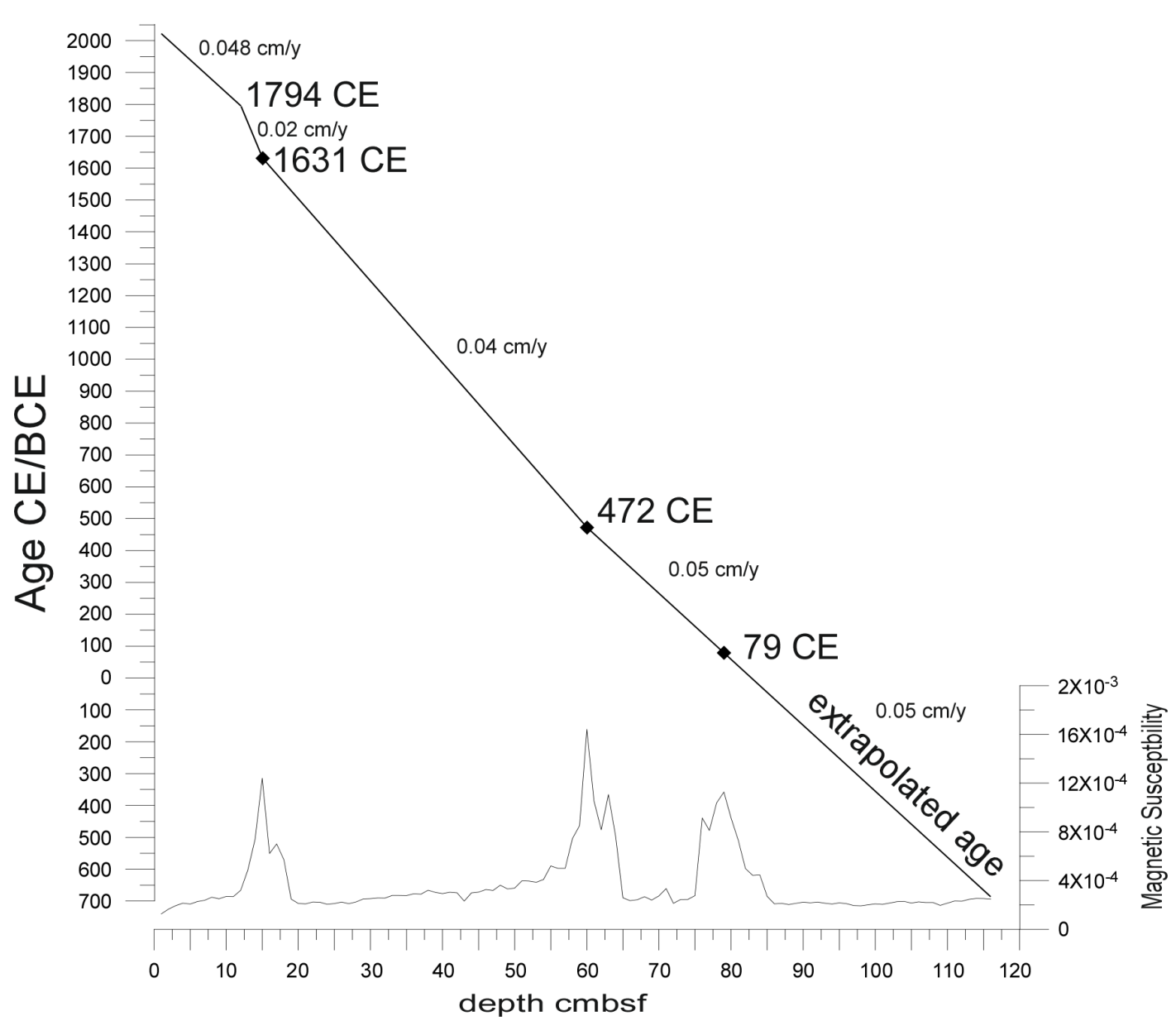

Figure 2. SW104-ND14Q age-depth model and magnetic susceptibility signal. Sedimentation rate and tephra layers (diamond) were reported.

\section{Core C5 Composite}

192 To investigate the reliability of the reworked coccoliths as a regional proxy of precipitation,

193 we also used the central Tyrrhenian Sea shallow sequence C5 Composite (C5Comp) (Fig.1).

194 The location of this site in front of Volturno River mouth makes it particularly suitable for

195 reconstructing runoff variability and for comparing coastal and open sea sites (Bonomo et al.,

196 2016). The core C5Comp is a composite marine sequence consisting of two cores: the

197 SW104-C5 and core C5 (710 cmbsf length) both recovered in the Gulf of Gaeta, at $93 \mathrm{~m}$

198 water depth (see Margaritelli et al., 2016 for details). Calcareous nannofossils of the core

199 SW104-C5 (back to 1630 CE) was already published by Bonomo et al. (2016). In this work

200 we extended their reconstruction back to $\sim 400$ CE. The chronology used is that of

201 Margaritelli et al. (2016) and has been assembled combining radionuclides ages $\left({ }^{210} \mathrm{~Pb}\right.$

202 activity-depth profile and ${ }^{137}$ Cs activity) for the last ca. 150 years, planktonic foraminiferal 
event, tephrostratigraphy and oxygen stable isotope correlation with other marine sites (for

204 details see Margeritelli et al., 2016). The age-depth profile has been constructed by a linear 205 interpolation between the tie-points showing a progressive decrease in sedimentation rate 206 from the top down to the base core.

207 The analysed time interval of core C5Comp covers the period between $\sim 400$ and $2013 \mathrm{CE}$ 208 with a mean temporal resolution of $\sim 10$ yrs.

209 Calcareous Nannofossils

210116 samples of the SW104-ND14Q core and 108 of the C5Comp were prepared as standard 211 smear slides (Bown, 1998) and analyzed with a transmitted light microscope at $\mathrm{x} 1250$ 212 magnification. Some samples of SW104-ND14Q core were analysed with a scanning electron 213 microscope (SEM) in order to solve taxonomic identification for smaller placoliths difficult to 214 achieve by light microscope (e.g., Emiliania huxleyi). The relative abundance of in situ species was estimated only in the SW104-ND14Q core based on the count of at least 600 216 specimens. The abundance of reworked nannofossils was estimated in the SW104-ND14Q 217 and C5Comp as the number of reworked specimens encountered during the count of the in 218 situ coccoliths. All abundances are expressed in percentages. SW104-ND14Q coccolith 219 species abundances were also used to calculate the N-ratio as defined by Flores et al. (2000) 220 to assess the nutricline depth fluctuations. The N-ratio is based on the absolute abundances of 221 the main surface r-strategist species (in our record E. huxleyi and small placoliths) over that of 222 F. profunda (lower photic zone taxon). High values of the N-ratio indicate shallow 223 nutricline/thermocline (relatively high surface coccolithophorid productivity) while low 224 values indicate deep nutricline/thermocline (relatively low surface coccolithophorid 225 productivity). As small placoliths, we counted the placoliths not confidently recognizable as 226 E. huxleyi and Reticulofenestra spp. 
Finally, the reworked coccoliths (RC) group includes taxa from different stratigraphic

228 intervals (Mesozoic, early Cenozoic) and Cenozoic long-range taxa showing poor preservation (etching and/or overgrowth). Raw data are shown in supplementary material.

Ecology of selected taxa

E. huxleyi tolerates a wide range of ecological conditions and is therefore abundant in nearly all oceanic environments (Schwab et al., 2012). This species is considered an opportunistic (rstrategist) taxon capable to quickly respond to nutrient availability in both eutrophic and oligotrophic areas (e.g., Balestra et al., 2008; Broerse et al., 2000; Dimiza et al., 2008, 2015; Haidar and Thierstein, 2001). E. huxleyi is generally more abundant in temperate (cold) mixed surface waters (e.g., Hagino et al., 2000; Malinverno et al., 2003), but may also be found in stable regimes in terms of vertical mixing with relatively high nutrient availability (Andruleit et al., 2005). Ausín et al. (2015) further postulated that E. huxleyi (size >4 m) can find optimal conditions for its development in cold water that are also low-salinity.

The lower photic zone species $F$. profunda has a more constrained habitat and has thus been widely used to monitor past changes in nutricline-depth and induced changes in surface productivity (Beaufort, 1997). The abundance of $F$. profunda increases with respect to other

244 coccolithophores when the nutricline is deep and overlaid by a nutrient-depleted upper photic 245 layer (Balestra et al., 2008; Bown et al., 2009; Dimiza et al., 2015; Incarbona et al., 2008, 246 2010). These conditions generally reveal stable, stratified, oligotrophic surface waters during 247 summer months (Baumann et al., 2005; Malinverno et al., 2009) that can be disrupted under 248 increased wind stress and / or upwelling and divergence circulation (Bown et al., 2009). 249 Hernández-Almeida et al. (2019), using F. profunda relative abundance vs MODIS (Moderate 250 Resolution Imaging Spectroradiometer) chlorophyll- $\alpha$, show a pronounced temperature 251 sensitivity of $F$. profunda and no correlation whit surface net primary production at latitudes 252 higher than $30^{\circ} \mathrm{N}-30^{\circ} \mathrm{S}$, such as Mediterranean area. Contrary, Grelaud et al. (2012) showed a 
strong anticorrelation $(\mathrm{R}=-0.76)$ between $F$. profunda $\%$ and chlorophyll- $\alpha$ in the Aegean

254 Sea (eastern Mediterranean Sea).

255

256

257

\section{Biomarker analyses}

Sea surface temperature and TERR-alkane reconstructions along the SW104-ND14Q core have been published by Jalali et al (2018). The method used for biomarker analyses have been described by (Sicre et al., 2002). Fatty alcohol biomarker data were used to calculate the $C_{26}$ fatty alcohol / $\mathrm{C}_{29}$ n-alkane $+\mathrm{C}_{26}$ fatty alcohol ratio $\left(\mathrm{C}_{26 \mathrm{OH}} /\left(\mathrm{C}_{26 \mathrm{OH}}+\mathrm{C}_{29}\right)\right)$. This ratio was determined along the core to infer information on water oxygenation as proposed by Cacho et al. (2000). High values of this ratio presumably correspond to low ventilation and vice versa.

\section{Results}

The coccolithophore assemblages in the SW104-ND14Q core are generally well preserved and abundant. E. huxleyi dominates the assemblages with an average abundance of $\sim 80 \%$. $F$. profunda is also well represented with an average abundance of $\sim 10 \%$. Other taxa are largely subordinated with percentages ranging between $\sim 1$ - 3\% (e.g. Syracosphaera, Rhabdosphaera and Calciosolenia) and no significant variations (not shown). Reworked specimens are always present and are found in higher amounts in the upper part of the core. E. huxleyi, F. profunda, RC, and the N-ratio data shown in Figure 3 are used for the discussion.

E. huxleyi abundance range from 65 to $90 \%$ (Fig. 3a). Its downcore distribution pattern can be divided into two major intervals. A first one that includes the late Iron Age (IA) and the almost entire Roman Period (RP; between $~ 700$ BCE and $~ 400 \mathrm{CE}$ ) with abundance above $80 \%$. This period is followed by a decline to lower values $(<65 \%)$ between $\sim 400$ and $\sim 800$ CE, i.e. from the late RP throughout the Dark Age (DA). E. huxleyi returns to moderately higher abundances $(65-75 \%)$ at the late DA and during the Medieval Climate Anomaly (MCA) (800 to $1100 \mathrm{CE}$ ). Then, values remain approximately at these levels but with superimposed short-lived oscillations especially during the upper LIA. The distribution of $F$. 
profunda (Fig. 3b) reveals three main intervals: the first one runs from the bottom of the core 280 till $400 \mathrm{CE}$ and is characterized by fluctuating values between 7 and $9 \%$. Over the second 281 interval, from 400 to $1200 \mathrm{CE}$, the taxon abundances increase almost continuously, except for 282 two time spans of strong decrease centred at 600 and 900 CE. From 1200 CE, F. profunda 283 declines till $1550 \mathrm{CE}$ and rises again to Present day values. As shown in Fig. 3d, the N-ratio 284 shows similar trends as E. huxleyi, but with more pronounced fluctuations especially in the 285 upper half of the core. During the first 1200 years (700 BCE - $400 \mathrm{CE}$ ) the N-ratio value is > 286 0.9. At $\sim 400 \mathrm{CE}$ a sharp drop sets the beginning of a long-term decreasing trend till Present 287 that suggests a progressive reduction of coccolithophorid productivity.

$288 \mathrm{RC}$ percentages (\%RC) along the core range from $\sim 3$ to $\sim 25 \%$, and depict a steady increase 289 from the bottom core to $800 \mathrm{CE}$. Then, after a period of lower values around $900 \mathrm{CE}$ and $2901300 \mathrm{CE}, \% \mathrm{RC}$ increases up to Present with the highest values (17-25\%) during the LIA 291 ( 1400 -1800 CE) (Fig. 3c). In the C5Comp core, \%RC ranges from $\sim 14$ to $\sim 79 \%$ with lowest 292 levels found between 400 and $~ 1350$ CE. 
(a)

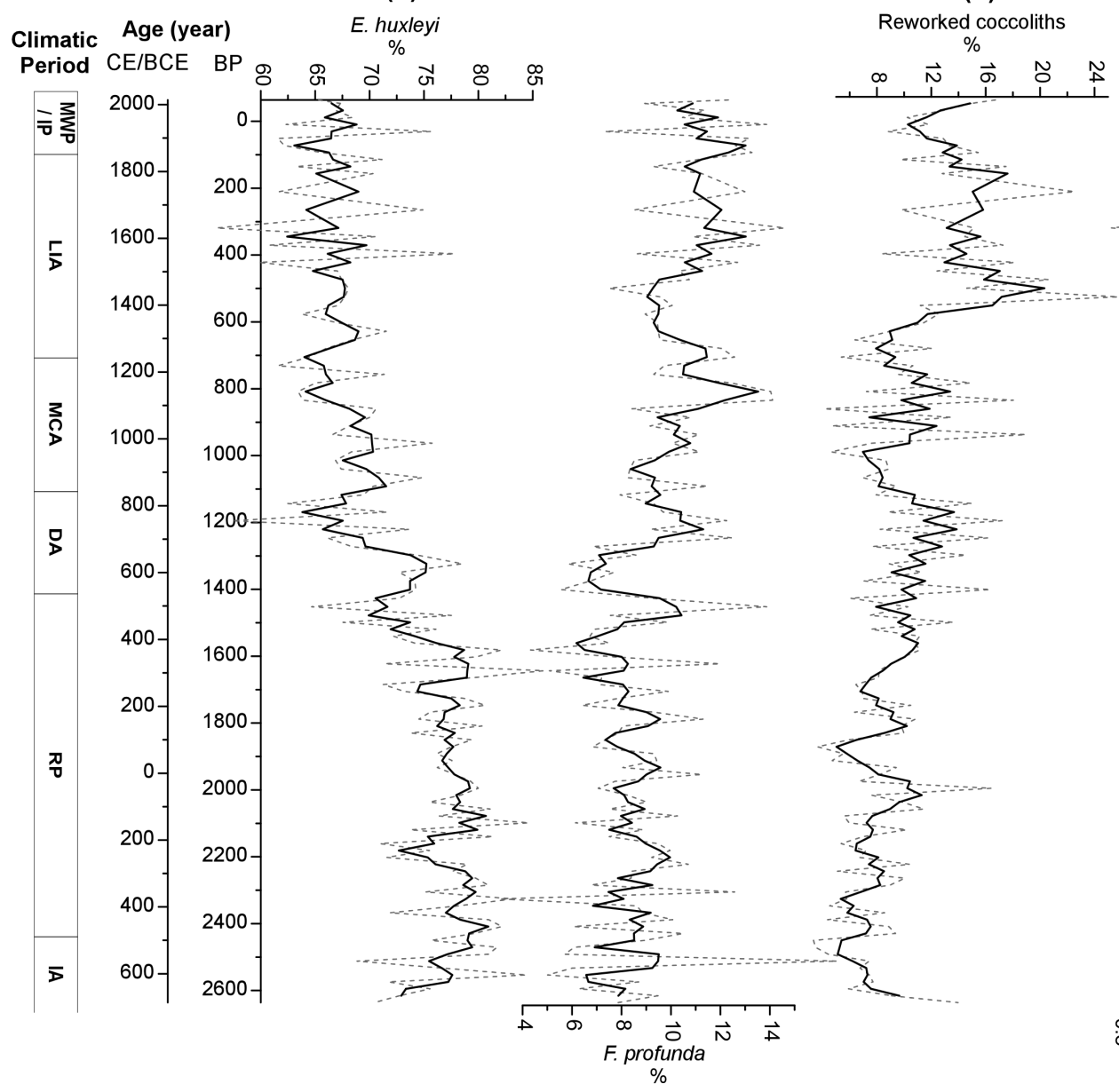

(b)

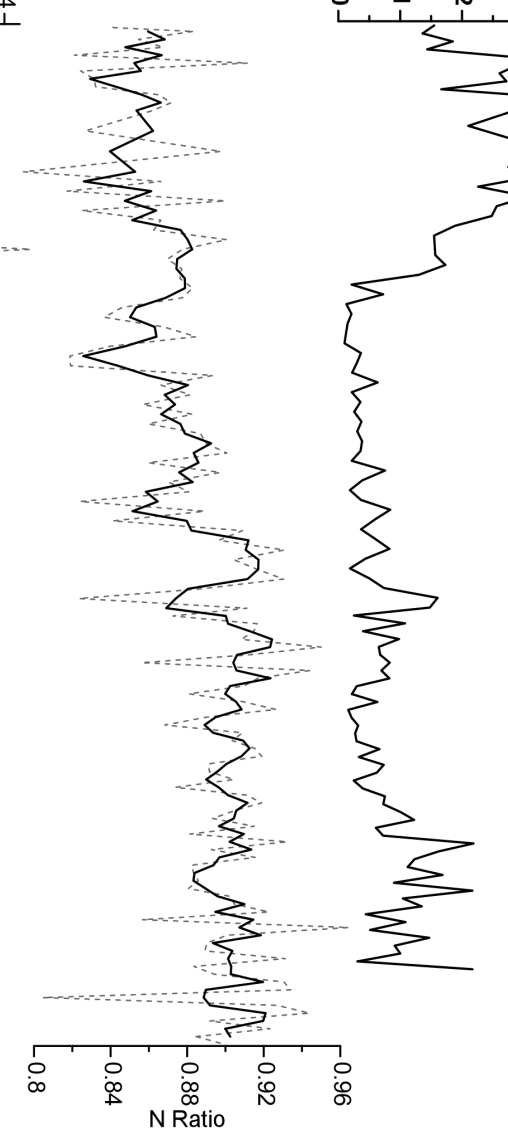

(d)
294

Figure 3. Time domain distribution of (a) E. huxleyi, (b) F. profunda, (c) RC, (d) N-ratio, and (e) $\mathrm{C}_{26 \mathrm{OH}} / \mathrm{C}_{29}+\mathrm{C}_{26 \mathrm{OH}}$ ratio in core SW104-ND14Q. Raw and three points running average data are reported in grey dashed and black full lines, respectively. The age model is from Jalali et al. (2018) and the climate period intervals are those of Margaritelli et al. (2016).

\section{Discussion}

\section{Reworked coccoliths and runoff fluctuations}

The NAO is one of the dominant atmospheric mode of variability in the North Atlantic sector that has a considerable influence on winter temperature/precipitation in Europe including the Mediterranean region (Hurrell, 1995). In the central Mediterranean, positive NAO conditions result in colder and drier winters than average, while winters are warmer and wetter during negative phases of NAO (Benito et al., 2015; López-Moreno et al., 2011a, 2011b; and references within). Bonomo et al. (2016) were able to evidence a negative correlation between the NAO index of Trouet et al. (2009) and the \% RC in the Central Tyrrhenian Sea core 
SW104-C5 over the last 400 years. Our results show that this relationship could have persisted back to $\sim 700 \mathrm{BCE}$ (Fig. 4). The resemblance between the \%RC short and long term trends the flood frequency in Southern Alps (Wirth et al., 2013) and the Southern Tyrrhenian marine record (Gulf of Salerno; Lirer et al. 2013) seems to confirm the link between the \%RC and runoff/precipitation in the region on longer time span (Bonomo et al., 2016a; Incarbona et al., 2010; Sprovieri et al., 2006). This finding is supported by the slight negative correlation

314 between the NAO index of Trouet et al. (2009) $\left(\mathrm{r}=-0.4 p=5^{-33}, \mathrm{n}=34\right)$ and Olsen et al. (2012) $315(\mathrm{r}=-0.2 p=0.01, \mathrm{n}=82)$ and the $\% \mathrm{RC}$ along the SW104 record. Our data agree with the negative correlation between NAO and winter precipitation, for the 1950-2006 period, 317 reconstructed over large areas of Morocco and Tunisia, most of the Iberian Peninsula, 318 southeastern France, Italy, the Balkan Peninsula, and large areas of central and northern 319 Turkey (López-Moreno et al., 2011a). Notwithstanding the age models accuracy of the different cores, the main drier spells recorded in the SAS, in the Central and Southern Tyrrhenian as shown by red dots in Fig. 4 might be considered synchronous as well to the XRF Si fluctuations found in lake sediments of Iberian Peninsula (Moreno et al., 2012). A noteworthy result is the high \% RC (RC Acme event) during the late LIA, between $\sim 1600$ and $\sim 1850 \mathrm{CE}$, that coincides with a long standing interval of negative NAO and is consistent with a regional scale humid period already documented in marine and continental sedimentary sequences of the Western and Central Mediterranean (e.g., Barrera-Escoda and Llasat, 2015;

327 Goudeau et al., 2015; Vallefuoco et al., 2012; Moreno et al. 2012) .

328 Jalali et al. (2018) highlighted similarities between the TERR-alkane record in SW104329 ND14Q and the forested fraction of usable land (FF) in Central and Western Europe (Fig.4 f, 330 i) (Kaplan et al., 2009). Considering that FF fluctuations are indicative of anthropogenic 331 deforestation (Kaplan et al., 2009), they concluded that TERR-alkane at SW104-ND14Q 332 reflects primarily human activity rather than climate fluctuations. Since the RC signal does 333 not match with either the TERR-alkanes or FF index but with the flood activity 
reconstruction and the $\mathrm{C}_{26 \mathrm{OH}} /\left(\mathrm{C}_{26 \mathrm{OH}}+\mathrm{C}_{29}\right)$ ratio (Fig.4), we suggest that $\mathrm{RC}$ reflect

335 precipitation changes that are also seen in other Mediterranean RC records overall supporting

336 the hypothesis that \% RC is a reliable index of past runoff/precipitation changes in the region.
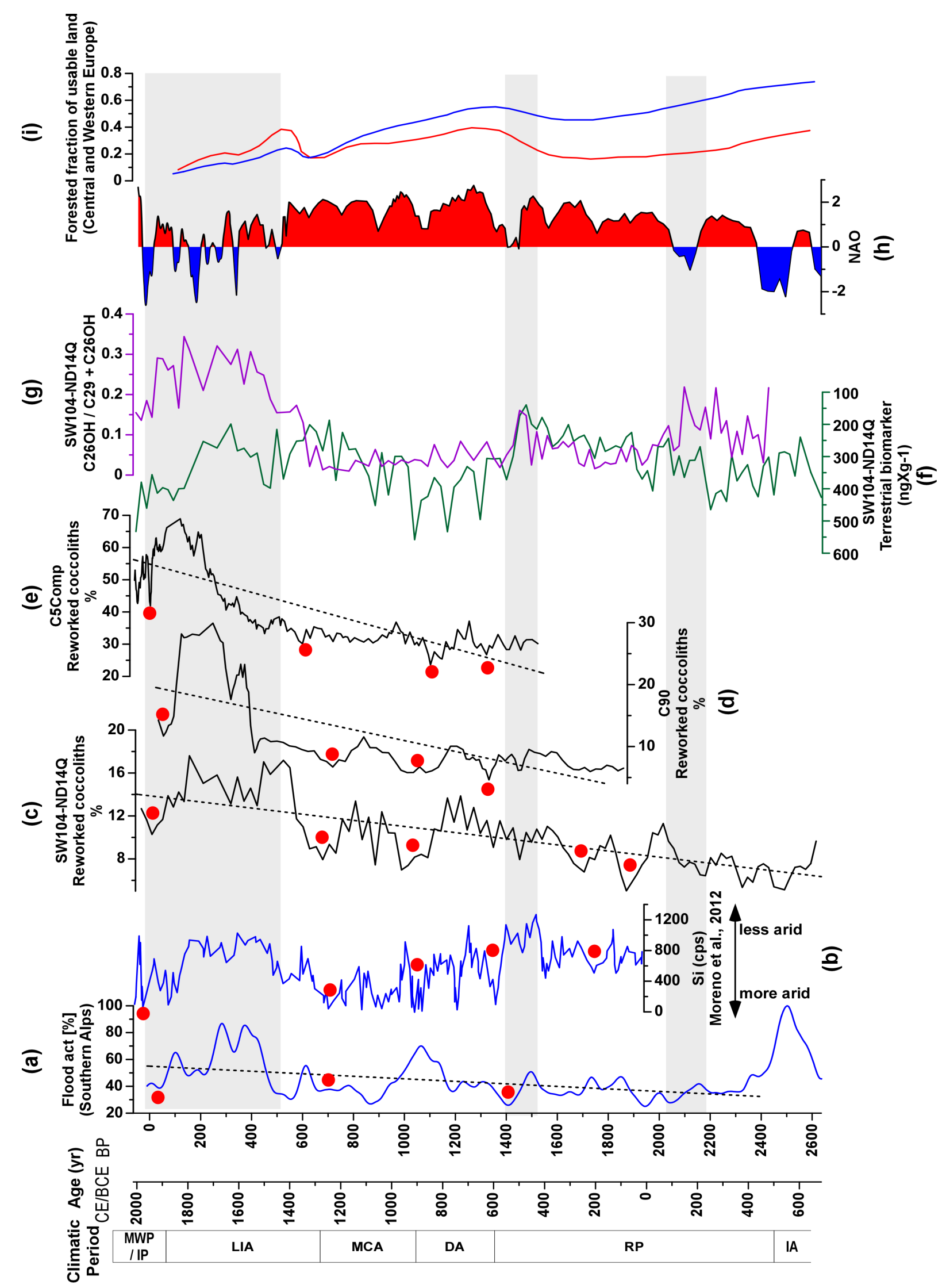
Figure 4. Comparison in time domain between (c) SW104-ND14Q, (d) C90, and (e) C5Comp reworked coccoliths, (g) SW104-ND14Q $\mathrm{C}_{26 \mathrm{OH}} / \mathrm{C}_{29}+\mathrm{C}_{26 \mathrm{OH}}$ ratio, (b) Si fluctuations (Moreno et al., 2012), and (a) Flood frequency reconstruction from Southern Alps (Wirth et al., 2013). (f) Terrestrial biomarker concentration (Jalali et al., 2018) and (i) Forest fraction of usable land (Kaplan et al., 2009) are reported. The dots mark the dry spells identified in the records. The bands highlight the relationship between $\mathrm{C}_{26 \mathrm{OH}} / \mathrm{C}_{29}+\mathrm{C}_{26 \mathrm{OH}}$ ratio and negative (h) NAO states. The climate periods are from Margaritelli et al. (2016).

\section{$N$-ratio and South Adriatic hydrology}

Highest N-ratio values almost all along the RP indicate shallow nutricline (surface productive waters) during this period considered as generally mild (Figs. 3, 5). This is in contrast with the LIA showing deep nutricline (lower surface productivity levels) (Figs. 3, 5), a cold period that one would expect to be favourable to water column mixing and growth of r-strategy taxa E. huxleyi. Comparable results has been recorded in the North Aegean Sea during the last 1500 years (Gogou et al., 2016; Skampa et al., 2019). In particularly, in the North Aegean Sea Gogou et al.( 2016) and Skampa et al. (2019) recorded periodic occurrence of "E. huxleyi dominance" intervals indicating strong water column convection coupled with NAO positive shifts , EMT-like events (Incarbona et al., 2016), cool spells, and enhanced continental inputs as well. In contrast, the occurrence of $F$. profunda dominance intervals may be linked to enhanced stratification of the upper water column and warm surface waters, potentially associated with increased lower salinity Black Sea Water intrusion. During the RP, alkenonederived SSTs show cold oscillations that do not seem to have any relationship with the Nratio (Fig. 5 a, d). Local atmospheric and hydrological conditions (i.e. properties of inflowing waters into the basin and strength of SAG) play an important role in the stratification of the

362 upper water column and associated changes in productivity (Civitarese et al., 2010; Ljubimir 363 et al., 2017; Vilibić et al., 2012). Several studies in open sea SAS waters have linked high 364 abundances of coccolithophorids with the inflow of saltier Ionian waters (Fonda Umani, 1996; Totti et al., 2000). In contrast, Ljubimir et al. (2017) reported higher abundances of coccolithophorids in lower salinity SAG waters during years of anticyclonic mode of the 
BiOS and their absence during cyclonic BiOS years. However, despite the lack of significant

368

369

370

371

372

373

374

375

376

377

378

379

380

381

382

383

384

385

386

387

correlation between salinity and total coccolithophore abundances, increased abundance of $E$. huxleyi has been often related to the inflow of LIW or eastern Mediterranean surface waters (Malinverno et al., 2003; Skejić et al., 2018). Advection of saltier LIW by promoting deep convection (Gačić et al., 2014) would favour the development of E. huxleyi known to rapidly respond to increased nutrient supply to the photic zone (Fig.5 g) (Malinverno et al., 2003). Conversely, reduced inflow of LIW, or enhanced input of less salty waters (mainly the WAC, and occasionally the MAW), and a weak SAG, would lead to higher surface water buoyancy and stratified conditions (Fig.5 f, g). The consequent deepening of the nutricline would thus favour $F$. profunda growth (Fig. $5 \mathrm{f}$ ). This conceptual scheme is in agreement with the slight negative correlation $\left(\mathrm{r}=-0.44 ; p=6^{-7}\right)$ between the $\mathrm{N}$-ratio and \% RC values. For instance, higher values of \% RC associated with sustained negative NAO during the LIA are coherent with higher precipitation and runoff (Bonomo et al., 2016a; Incarbona et al., 2010; Sprovieri et al., 2006) and the Po River flood record (Camuffo and Enzi, 1996). Rising $\mathrm{C}_{26 \mathrm{OH}} /\left(\mathrm{C}_{26 \mathrm{OH}}+\mathrm{C}_{29}\right)$ ratio to their highest values suggests an abrupt reduction of water oxygenation that is also compatible with stratified conditions caused by the large freshwater discharge during the LIA and lowest N-ratios. Similar observation can be made for two intervals of weaker NAO, i.e. around $200 \mathrm{BCE}$ and around $500 \mathrm{CE}$.

Regarding nutrient supply, our results also support the idea of a limited influence of the Po River (and secondary Apennines rivers) on the nutrient budget of the open SAS surface waters and coccolithophore productivity, as the nutrients are usually rapidly consumed during their transport within the WAC. The same have been observed around the eastern Adriatic coasts (Vilibić et al., 2012). Overall, our findings suggest that fresh water input due to increased precipitation and river runoff impact essentially on buoyancy and subsequent stratification in the SAG. 
392 Apart from the LIA and these two major short time intervals that all took place during

393 prolonged negative NAO, other N-ratio fluctuations cannot robustly be attributed to NAO and

394 high river discharge (Fig. 5). Under weaker freshwater forcing, other factors such as the BiOS

395 circulation may have been a more important controlling factor on the SAG dynamics and

396 productivity, but this question will need further investigations to be addressed. 


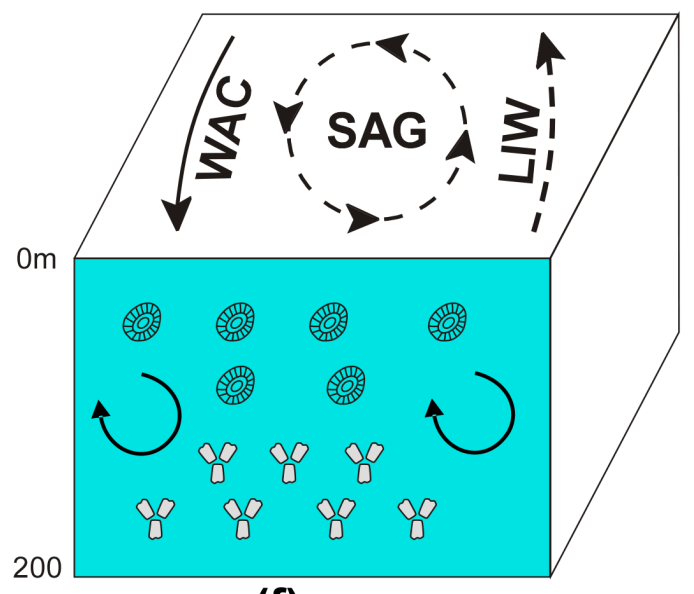

(f)

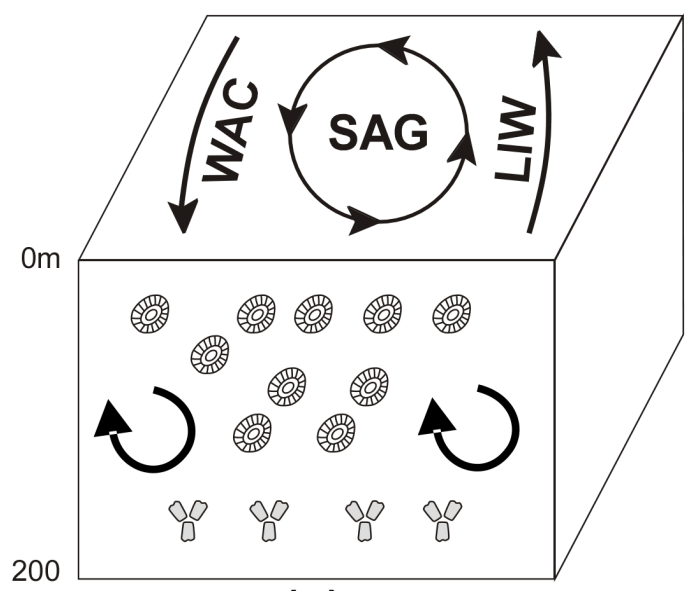

(g)

(2) (n)

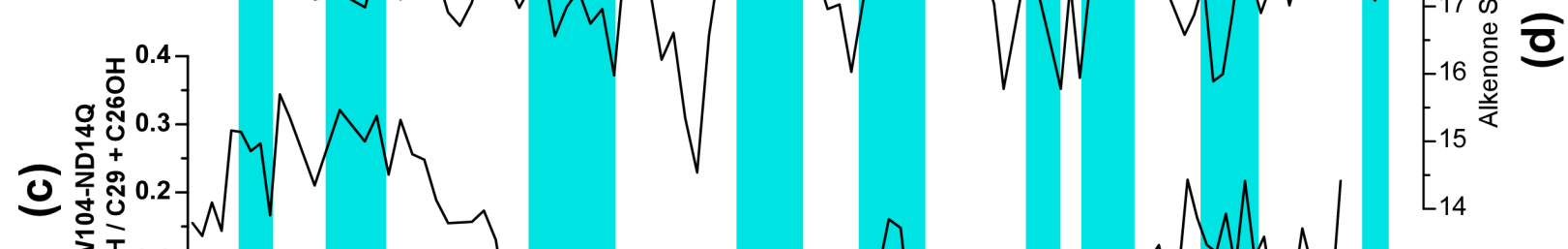

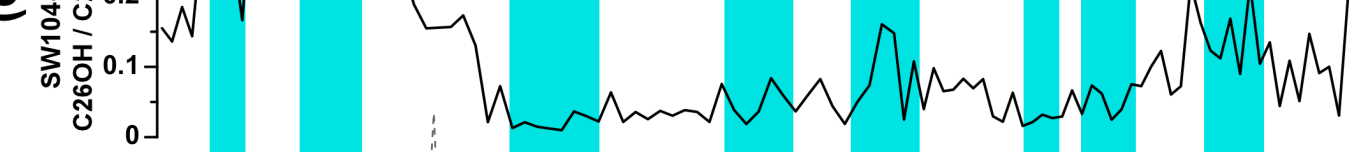

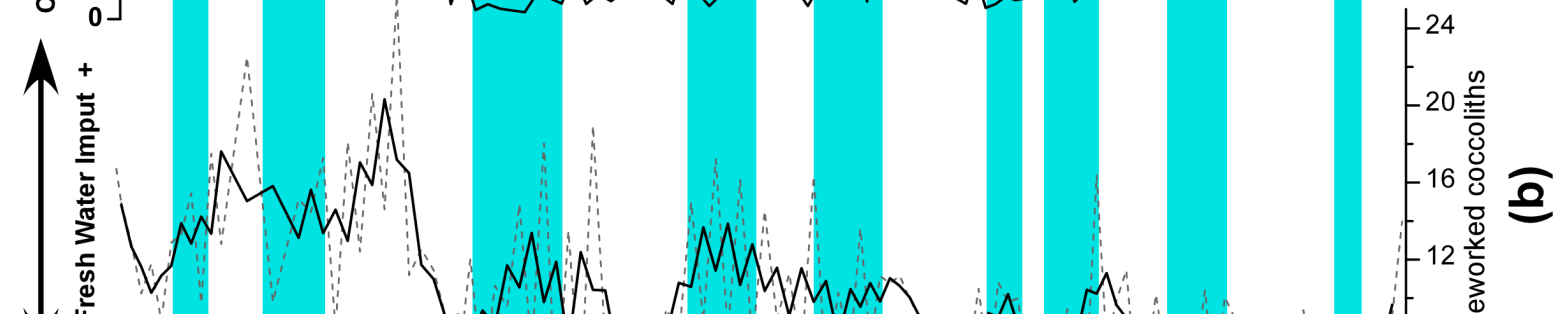

MVA Mn

Vin $-8 \stackrel{2}{\simeq}$

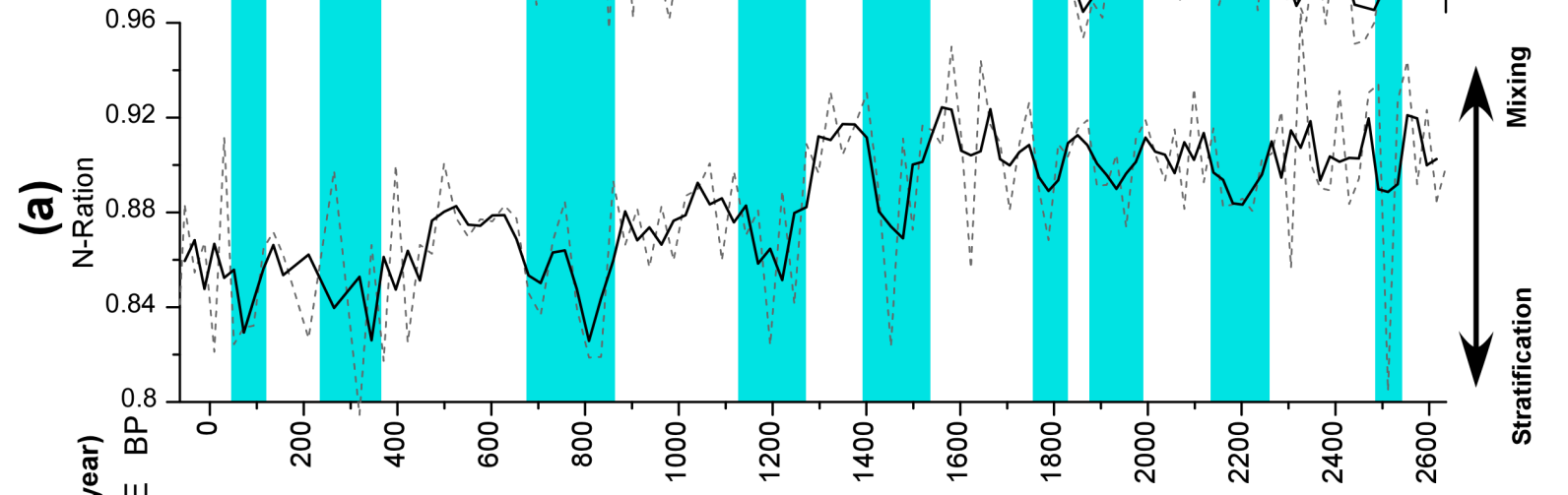

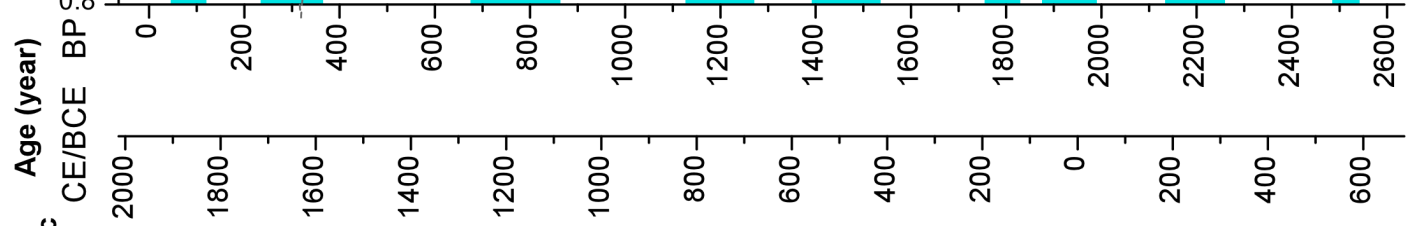

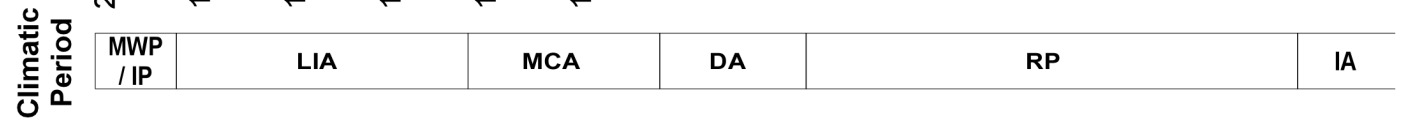


Figure 5. Schematic view of inferred relationship between (a) SW104-ND14Q N-Ratio and (f, g) SAS hydrology. (b) \%RC fluctuations, (c) $\mathrm{C}_{26 \mathrm{OH}} / \mathrm{C}_{29}+\mathrm{C}_{26 \mathrm{OH}}$ ratio, (d) SSTs fluctuations, and (e) winter NAO index (Olsen et al., 2012; Trouet et al., 2009) are reported. The bands highlight the N-Ratio during periods of stratified surface water (diagram $f$ ). The climate periods are from Margaritelli et al. (2016).

\section{Conclusion}

This high-resolution study of calcareous nannofossils from the sediment core SW104-ND14Q

406 was used to provide information on paleoceanographic and climatic conditions in the SAS, over the past $\sim 2700$ years. Based on the distribution of E. huxleyi, F. profunda, the N-ratio, and reworked coccoliths we were able to evidence hydrological variability and related coccolithophore production changes in the SAG.

One outstanding result is the good correspondence we found between the \% reworked coccoliths in the SAS and Tyrrhenian Sea cores and flood activity across the Southern Alps, highlighting the value of $\% \mathrm{RC}$ as a proxy for reconstructing regional scale precipitation and runoff.

We also showed that lowest N-ratio took place during extended weakest NAO phases, i.e. primarily the LIA and two other intervals (200BCE and 500CE), as a result of large fresh water discharge and subsequent stratified surface ocean reducing nutrient supply and production of coccolithophorids in the SAG. Outside these periods of strong negative NAO, whether and to what extent other factors such as the BIOS may have played a role on the hydrology and productivity of the SAG remains an open question.

\section{Acknowledgments}

We would like to thank the two anonymous reviewers for their useful and constructive comments. The core SW104-ND14Q has been collected by ISMAR-CNR (Napoli) aboard of the R/V-Urania during the oceanographic cruise NEXTADATA2014. This research has been financially supported by the Project of Strategic Interest NextData PNR 2011-2013 (www. nextdataproject.it), ERC Consolidator Grant (Project ID: 68323) “TIMED” Testing the role of 
Mediterranean thermohaline circulation as a sensor of transient climate events and shaker of North Atlantic Circulation", and MISTRALS/ PaleoMex program led by INSU/CNRS.

\section{References}

Andruleit H, Rogalla U and Stäger S (2005) Living coccolithophores recorded during the onset of upwelling conditions off Oman in the western Arabian Sea. J. Nannoplankton Res. 2 27(1): 1-14.

Artegiani A, Paschini E, Russo A, Bregant D, Raicich F and Pinardi N (1997) The Adriatic Sea General Circulation. Part II: Baroclinic Circulation Structure. Journal of Physical Oceanography 27(8): 1515-1532: doi:10.1175/15200485(1997)027<1515:TASGCP>2.0.CO;2.

Ausín B, Flores J-A, Sierro F-J, Bárcena M-A, Hernández-Almeida I, Francés G, et al. (2015) Coccolithophore productivity and surface water dynamics in the Alboran Sea during the last 25kyr. Palaeogeography, Palaeoclimatology, Palaeoecology 418: 126-140: doi:10.1016/j.palaeo.2014.11.011.

Balestra B, Marino M, Monechi S, Marano C and Locaiono F (2008) Coccolithophore communities in the Gulf of Manfredonia (Southern Adriatic Sea): Data from water and surface sediments. Micropaleontology 54(5): 377-396.

Barrera-Escoda A and Llasat MC (2015) Evolving flood patterns in a Mediterranean region (1301/2012) and climatic factors; the case of Catalonia. Hydrology and Earth System Sciences 19(1): 465-483: doi:10.5194/hess-19-465-2015.

Baumann K-H, Andruleit H, Böckel B, Geisen M and Kinkel H (2005) The significance of extant coccolithophores as indicators of ocean water masses, surface water temperature, and paleoproductivity: a review. Paläontologische Zeitschrift 79(1): 93-112: doi:10.1007/bf03021756.

Beaufort L (1997) Insolation Cycles as a Major Control of Equatorial Indian Ocean Primary 
453

454

455

456

457

458

459

460

461

462

463

464

465

466

467

468

469

470

471

472

473

474

475

476

477

478

Production. Science 278(5342): 1451-1454: doi:10.1126/science.278.5342.1451.

Benito G, Macklin MG, Zielhofer C, Jones AF and Machado MJ (2015) Holocene flooding and climate change in the Mediterranean. CATENA 130: 13-33:

doi:10.1016/j.catena.2014.11.014.

Bini M, Zanchetta G, Perşoiu A, Cartier R, Català A, Cacho I, et al. (2019) The 4.2 ka BP

Event in the Mediterranean region: an overview. Climate of the Past 15(2): 555-577:

doi:10.5194/cp-15-555-2019.

Bonomo S, Cascella A, Alberico I, Ferraro L, Giordano L, Lirer F, et al. (2014)

Coccolithophores from near the Volturno estuary (central Tyrrhenian Sea). Marine

Micropaleontology 111: 26-37: doi:10.1016/j.marmicro.2014.06.001.

Bonomo S, Cascella A, Alberico I, Sorgato S, Pelosi N, Ferraro L, et al. (2016a) Reworked

Coccoliths as runoff proxy for the last 400years: The case of Gaeta Gulf (central Tyrrhenian

Sea, Central Italy). Palaeogeography, Palaeoclimatology, Palaeoecology. Elsevier B.V. 459:

15-28: doi:10.1016/j.palaeo.2016.06.037.

Bonomo S, Cascella A, Alberico I, Sorgato S, Pelosi N, Ferraro L, et al. (2016b) Reworked

Coccoliths as runoff proxy for the last 400 years: The case of Gaeta Gulf (central Tyrrhenian

Sea, Central Italy). Palaeogeography, Palaeoclimatology, Palaeoecology 459: 15-28:

doi:10.1016/j.palaeo.2016.06.037.

Bown P (1998) Calcareous Nannofossil Biostratigraphy. London: Kluwer Academic.

Bown PR, Dunkley Jones T, Young JR and Randell R (2009) A palaeogene record of extant lower photic zone calcareous nannoplankton. Palaeontology: doi:10.1111/j.1475-

4983.2009.00853.x.

Broerse ATC, Ziveri P, van Hinte JE and Honjo S (2000) Coccolithophore export production, species composition, and coccolith-CaCO3 fluxes in the NE Atlantic. Deep Sea Research

Part II: Topical Studies in Oceanography 47(9-11): 1877-1905: doi:10.1016/S0967-

0645(00)00010-2. 
Cacho I, Grimalt JO, Pelejero C, Canals M, Sierro FJ, Flores JA, et al. (1999) Dansgaard-

480 Oeschger and Heinrich event imprints in Alboran Sea paleotemperatures. Paleoceanography 481 14(6): 698-705: doi:10.1029/1999PA900044.

482 Cacho I, Grimalt JO, Sierro FJ, Shackleton N and Canals M (2000) Evidence for enhanced 483 Mediterranean thermohaline circulation during rapid climatic coolings. Earth and Planetary 484 Science Letters 183(3-4): 417-429: doi:10.1016/S0012-821X(00)00296-X.

485 Camuffo D and Enzi S (1996) The analysis of two bi-millennial series: Tiber and Po river 486 floods. Climatic Variations and Forcing Mechanisms of the Last 2000 Years. Berlin, 487 Heidelberg: Springer Berlin Heidelberg, 433-450: doi:10.1007/978-3-642-61113-1_20. 488 Caroli I and Caldara M (2007) Vegetation history of Lago Battaglia (eastern Gargano coast, 489 Apulia, Italy) during the middle-late Holocene. Vegetation History and Archaeobotany 16(4): 490 317-327: doi:10.1007/s00334-006-0045-y.

491 Cerino F, Malinverno E, Fornasaro D, Kralj M and Cabrini M (2017) Coccolithophore 492 diversity and dynamics at a coastal site in the Gulf of Trieste (northern Adriatic Sea). 493 Estuarine, Coastal and Shelf Science. Elsevier Ltd: doi:10.1016/j.ecss.2017.07.013.

494 Cisneros M, Cacho I, Frigola J, Canals M, Masqué P, Martrat B, et al. (2016) Sea surface 495 temperature variability in the central-western Mediterranean Sea during the last 2700 years: A 496 multi-proxy and multi-record approach. Climate of the Past 12(4): 849-869: doi:10.5194/cp$497 \quad 12-849-2016$.

498 Civitarese G, Gačić M, Lipizer M and Eusebi Borzelli GL (2010) On the impact of the 499 Bimodal Oscillating System (BiOS) on the biogeochemistry and biology of the Adriatic and $500 \quad$ Ionian Seas (Eastern Mediterranean). Biogeosciences 7(12): 3987-3997: doi:10.5194/bg-7$501 \quad 3987-2010$.

502 Civitarese G, Gačić M, Vetrano A, Boldrin A, Bregant D, Rabitti S, et al. (1998) 503 Biogeochemical fluxes through the Strait of Otranto (Eastern Mediterranean). Continental 504 Shelf Research: doi:10.1016/S0278-4343(98)00016-8. 

al. (2013) Holocene vegetation and climate changes in the central Mediterranean inferred

507 from a high-resolution marine pollen record (Adriatic Sea). Climate of the Past: doi:10.5194/cp-9-2023-2013.

Di Bella L, Frezza V, Bergamin L, Carboni MG, Falese F, Martorelli E, et al. (2014)

Foraminiferal record and high-resolution seismic stratigraphy of the Late Holocene succession of the submerged Ombrone River delta (Northern Tyrrhenian Sea, Italy). Quaternary International 328-329(1): 287-300: doi:10.1016/j.quaint.2013.09.043.

513 Di Rita F and Magri D (2009) Holocene drought, deforestation and evergreen vegetation development in the central Mediterranean: A 5500 year record from Lago Alimini Piccolo, Apulia, southeast Italy. Holocene: doi:10.1177/0959683608100574.

Dimiza MD, Triantaphyllou M V., Malinverno E, Psarra S, Karatsolis B-T, Mara P, et al. (2015) The composition and distribution of living coccolithophores in the Aegean Sea (NE

518 Mediterranean). Micropaleontology.

Dimiza MD, Triantaphyllou MV V. and Dermitzakis MD (2008) Vertical distribution and ecology of living coccolithophores in the marine ecosystems of Andros Island (Middle Aegean Sea) during late summer 2001. Hellenic Journal of Geosciences 43: 1-7.

Faganeli J, Gačić M, Malej A and Smodlaka N (1989) Pelagic organic matter in the Adriatic

523 Sea in relation to winter hydrographic conditions. Journal of Plankton Research: doi:10.1093/plankt/11.6.1129.

Ferreira J and Cachão M (2005) Calcareous nannoplankton from the Guadiana estuary and 526 Algarve continental shelf (southern Portugal). Thalassas 21(1): 35-44.

527 Ferreira J, Cachão M and González R (2008) Reworked calcareous nannofossils as ocean 528 dynamic tracers: The Guadiana shelf case study (SW Iberia). Estuarine, Coastal and Shelf 529 Science 79(1): 59-70: doi:10.1016/j.ecss.2008.03.012.

530 Flores JA, Gersonde RR, Sierro FJ and Niebler HS (2000) Southern ocean pleistocene 
calcareous nannofossil events: Calibration with isotope and geomagnetic stratigraphies.

532

533

534

Marine Micropaleontology 40(4): 377-402: doi:10.1016/S0377-8398(00)00047-5.

Fonda Umani S (1996) Pelagic production and biomass in the Adriatic Sea. Scientia Marina.

Frigola J, Moreno a., Cacho I, Canals M, Sierro FJ, Flores J a., et al. (2007) Holocene climate variability in the western Mediterranean region from a deepwater sediment record.

Paleoceanography 22(2): 1-16: doi:10.1029/2006PA001307.

Gačić M, Civitarese G, Kovačević V, Ursella L, Bensi M, Menna M, et al. (2014) Extreme winter 2012 in the adriatic: An example of climatic effect on the biOS rhythm. Ocean Science: doi:10.5194/os-10-513-2014.

Gačić M, Civitarese G, Miserocchi S, Cardin V, Crise A and Mauri E (2002) The open-ocean convection in the Southern Adriatic: A controlling mechanism of the spring phytoplankton bloom. Continental Shelf Research: doi:10.1016/S0278-4343(02)00050-X.

Gacic M, Eusebi Borzelli GL, Civitarese G, Cardin V and Yari S (2010) Can internal processes sustain reversals of the ocean upper circulation? The Ionian Sea example. Geophysical Research Letters 37(9): 1-5: doi:10.1029/2010GL043216.

Gačić M, Marullo S, Santoleri R and Bergamasco A (1997) Analysis of the seasonal and interannual variability of the sea surface temperature field in the Adriatic Sea from AVHRR data (1984-1992). Journal of Geophysical Research: Oceans. John Wiley \& Sons, Ltd 102(C10): 22937-22946: doi:10.1029/97JC01720.

Giunta S, Negri a., Morigi C, Capotondi L, Combourieu-Nebout N, Emeis KC, et al. (2003) Coccolithophorid ecostratigraphy and multi-proxy paleoceanographic reconstruction in the Southern Adriatic Sea during the last deglacial time (Core AD91-17). Palaeogeography, Palaeoclimatology, Palaeoecology 190: 39-59: doi:10.1016/S0031-0182(02)00598-9. Godrijan J, Young JR, Marić Pfannkuchen D, Precali R and Pfannkuchen M (2018) Coastal zones as important habitats of coccolithophores: A study of species diversity, succession, and life-cycle phases. Limnology and Oceanography: doi:10.1002/1no.10801. 
558 Climate variability and socio-environmental changes in the northern Aegean (NE

559 Mediterranean) during the last 1500 years. Quaternary Science Reviews 136: 209-228:

560 doi:10.1016/j.quascirev.2016.01.009.

561 Goudeau MLS, Reichart GJ, Wit JC, de Nooijer LJ, Grauel AL, Bernasconi SM, et al. (2015)

562 Seasonality variations in the Central Mediterranean during climate change events in the Late

563 Holocene. Palaeogeography, Palaeoclimatology, Palaeoecology 418: 304-318:

564 doi:10.1016/j.palaeo.2014.11.004.

565 Grauel AL and Bernasconi SM (2010) Core-top calibration of $\delta 180$ and $\delta 13 \mathrm{C}$ of G. ruber

566 (white) and U. mediterranea along the southern Adriatic coast of Italy. Marine

567 Micropaleontology: doi:10.1016/j.marmicro.2010.09.003.

568 Grauel AL, Goudeau MLS, de Lange GJ and Bernasconi SM (2013) Climate of the past 2500

569 years in the Gulf of Taranto, central Mediterranean Sea: A high-resolution climate

570 reconstruction based on $18 \mathrm{O}$ and $13 \mathrm{C}$ of Globigerinoides ruber (white). The Holocene 23(10):

571 1440-1446: doi:10.1177/0959683613493937.

572 Guerreiro C, Oliveira A, de Stigter H, Cachão M, Sá C, Borges C, et al. (2013) Late winter

573 coccolithophore bloom off central Portugal in response to river discharge and upwelling.

574 Continental Shelf Research 59: 65-83: doi:10.1016/j.csr.2013.04.016.

575 Hagino K, Okada H and Matsuoka H (2000) Spatial dynamics of coccolithophore

576 assemblages in the Equatorial Western-Central Pacific Ocean. Marine Micropaleontology:

577 doi:10.1016/S0377-8398(00)00014-1.

578 Haidar AT and Thierstein HR (2001) Coccolithophore dynamics off Bermuda (N. Atlantic).

579 Deep-Sea Research Part II: Topical Studies in Oceanography 48(8-9): 1925-1956:

580 doi:10.1016/S0967-0645(00)00169-7.

581 Honjo S and Okada H (1974) Community structure of coccolithophores in the photic layer of 582 the mid-Pacific. Micropaleontology 20(2): 209-230. 
583

584

585

586

587

588

589

590

591

592

593

594

595

596

597

598

599

600

601

602

603

604

605

606

607

608

Hurrell JW (1995) Decadal Trends in the North Atlantic Oscillation: Regional Temperatures and Precipitation. Science 269(5224): 676-679: doi:10.1126/science.269.5224.676.

Ilijanić N, Miko S, Petrinec B and Franić Z (2014) Metal deposition in deep sediments from the Central and South Adriatic Sea. Geologia Croatica: doi:10.4154/gc.2014.14.

Incarbona A, Bonomo S, Di Stefano E, Zgozi S, Essarbout N, Talha M, et al. (2008)

Calcareous nannofossil surface sediment assemblages from the Sicily Channel (central

Mediterranean Sea): Palaeoceanographic implications. Marine Micropaleontology 67(3-4):

297-309: doi:10.1016/j.marmicro.2008.03.001.

Incarbona A, Martrat B, Mortyn PG, Sprovieri M, Ziveri P, Gogou A, et al. (2016)

Mediterranean circulation perturbations over the last five centuries: Relevance to past Eastern

Mediterranean Transient-type events. Scientific Reports 6(1): 29623: doi:10.1038/srep29623.

Incarbona A, Ziveri P, Di Stefano E, Lirer F, Mortyn G, Patti B, et al. (2010) Calcareous nannofossil assemblages from the Central Mediterranean Sea over the last four centuries: the impact of the little ice age. Climate of the Past Discussions 6(3): 817-866: doi:10.5194/cpd6-817-2010.

Jalali B, Sicre M-A, Bassetti M-A and Kallel N (2016) Holocene climate variability in the North-Western Mediterranean Sea (Gulf of Lions). Climate of the Past 12(1): 91-101: doi:10.5194/cp-12-91-2016.

Jalali B, Sicre M-A, Klein V, Schmidt S, Maselli V, Lirer F, et al. (2018) Deltaic and Coastal Sediments as Recorders of Mediterranean Regional Climate and Human Impact Over the Past Three Millennia. Paleoceanography and Paleoclimatology. John Wiley \& Sons, Ltd 33(6): 579-593: doi:10.1029/2017PA003298.

Kaplan JO, Krumhardt KM and Zimmermann N (2009) The prehistoric and preindustrial deforestation of Europe. Quaternary Science Reviews: doi:10.1016/j.quascirev.2009.09.028. Kouli K, Gogou A, Bouloubassi I, Triantaphyllou MV, Ioakim C, Katsouras G, et al. (2012) Late postglacial paleoenvironmental change in the northeastern Mediterranean region: 
609 Combined palynological and molecular biomarker evidence. Quaternary International 261:

610 118-127: doi:10.1016/j.quaint.2011.10.036.

611 Leider A, Hinrichs KU, Mollenhauer G and Versteegh GJM (2010) Core-top calibration of

612 the lipid-based U37K' and TEX86temperature proxies on the southern Italian shelf (SW

613 Adriatic Sea, Gulf of Taranto). Earth and Planetary Science Letters:

614 doi:10.1016/j.epsl.2010.09.042.

615 Lirer F, Sprovieri M, Ferraro L, Vallefuoco M, Capotondi L, Cascella A, et al. (2013)

616 Integrated stratigraphy for the Late Quaternary in the eastern Tyrrhenian Sea. Quaternary

617 International 292: 71-85: doi:10.1016/j.quaint.2012.08.2055.

618 Lirer F, Sprovieri M, Vallefuoco M, Ferraro L, Pelosi N, Giordano L, et al. (2014) Planktonic

619 foraminifera as bio-indicators for monitoring the climatic changes that have occurred over the 620 past 2000 years in the southeastern Tyrrhenian Sea. Integrative Zoology 9(4): 542-554:

621 doi:10.1111/1749-4877.12083.

622 Ljubimir S, Jasprica N, Čalić M, Hrustić E, Dupčić Radić I, Car A, et al. (2017) Interannual 623 (2009-2013) variability of winter-spring phytoplankton in the open South Adriatic Sea:

624 Effects of deep convection and lateral advection. Continental Shelf Research 143: 311-321:

625 doi:10.1016/j.csr.2017.05.007.

626 López-Moreno JI, Vicente-Serrano SM, Morán-Tejeda E, Lorenzo-Lacruz J, Kenawy A and 627 Beniston M (2011a) Effects of the North Atlantic Oscillation (NAO) on combined 628 temperature and precipitation winter modes in the Mediterranean mountains: Observed 629 relationships and projections for the 21st century. Global and Planetary Change:

630 doi:10.1016/j.gloplacha.2011.03.003.

631 López-Moreno JI, Vicente-Serrano SM, Moran-Tejeda E, Zabalza J, Lorenzo-Lacruz J and 632 García-Ruiz JM (2011b) Impact of climate evolution and land use changes on water yield in 633 the ebro basin. Hydrology and Earth System Sciences 15(1): 311-322: doi:10.5194/hess-15634 311-2011. 
636 modelling of late Quaternary marine sequences in the Adriatic: Towards improved precision 637 and accuracy using volcanic event stratigraphy. Continental Shelf Research 27(3-4): 560638 582: doi:10.1016/j.csr.2005.12.017.

639 Malinverno E, Triantaphyllou M V., Stavrakakis S, Ziveri P and Lykousis V (2009) Seasonal 640 and spatial variability of coccolithophore export production at the South-Western margin of 641 Crete (Eastern Mediterranean). Marine Micropaleontology. Elsevier B.V. 71(3-4): 131-147: 642 doi:10.1016/j.marmicro.2009.02.002.

643 Malinverno E, Ziveri P and Corselli C (2003) Coccolithophorid distribution in the Ionian Sea 644 and its relationship to eastern Mediterranean circulation during late fall to early winter 1997. 645 Journal of Geophysical Research 108(C9): 2156-2202: doi:10.1029/2002JC001346.

646 Manca BB, Kovaevi V, Gai M and Viezzoli D (2002) Dense water formation in the Southern 647 Adriatic Sea and spreading into the Ionian Sea in the period 1997-1999. Journal of Marine 648 Systems: doi:10.1016/S0924-7963(02)00056-8.

649 Marchini G, Zanchetta G, Santacroce R, Vigliotti L, Capotondi L and Sulpizio R (2014) 650 Tephrostratigraphy of Marine Core AD91-17 ( Adriatic Sea ) Revised. Alpine and 651 Mediterranean Quaternary.

652 Margaritelli G, Cisneros M, Cacho I, Capotondi L, Vallefuoco M, Rettori R, et al. (2018) 653 Climatic variability over the last 3000 years in the central - western Mediterranean Sea 654 (Menorca Basin) detected by planktonic foraminifera and stable isotope records. Global and 655 Planetary Change 169: 179-187: doi:10.1016/j.gloplacha.2018.07.012.

656 Margaritelli G, Vallefuoco M, Di Rita F, Bellucci L, Insinga DD, Petrosino P, et al. (2016) 657 Climate events from a shallow water marine record of the Central Tyrrhenian during the last 658 four millennia. Global and Planetary Change 141: doi:10.1016/j.gloplacha.2016.04.007.

659 Martrat B, Grimalt JO, Lopez-Martinez C, Cacho I, Sierro FJ, Flores JA, et al. (2004) Abrupt 660 temperature changes in the Western Mediterranean over the past 250,000 years. Science (New 
661

662

663

664

665

666

667

668

669

670

671

672

673

674

675

676

677

678

679

680

681

682

683

684

685

686 Reale M, Crise A, Farneti R and Mosetti R (2016) A process study of the Adriatic-Ionian

York, N.Y.) 306(5702): 1762-1765: doi:10.1126/science.1101706.

Matthews IP, Trincardi F, Lowe JJ, Bourne AJ, MacLeod A, Abbott PM, et al. (2015)

Developing a robust tephrochronological framework for Late Quaternary marine records in the Southern Adriatic Sea: New data from core station SA03-11. Quaternary Science Reviews: doi:10.1016/j.quascirev.2014.10.009.

Moreno A, Pérez A, Frigola J, Nieto-Moreno V, Rodrigo-Gámiz M, Martrat B, et al. (2012)

The Medieval Climate Anomaly in the Iberian Peninsula reconstructed from marine and lake records. Quaternary Science Reviews: doi:10.1016/j.quascirev.2012.04.007.

Narciso Á, Flores J-A, Cachão M, Piva A, Asioli A, Andersen N, et al. (2012) Late GlacialHolocene transition in the southern Adriatic Sea: Coccolithophore and Foraminiferal evidence. Micropaleontology 58(6): 523-538: doi:10.2307/24413309.

Oldfield F, Asioli A, Accorsi CA, Mercuri AM, Juggins S, Langone L, et al. (2003) A high resolution late Holocene palaeo environmental record from the central Adriatic Sea.

Quaternary Science Reviews 22(2-4): 319-342: doi:10.1016/S0277-3791(02)00088-4.

Pérez-Folgado M, Sierro FJ, Flores J a., Grimalt JO and Zahn R (2004) Paleoclimatic

variations in foraminifer assemblages from the Alboran Sea (Western Mediterranean) during the last $150 \mathrm{ka}$ in ODP Site 977. Marine Geology 212(1-4): 113-131:

doi:10.1016/j.margeo.2004.08.002.

Pinardi N, Zavatarelli M, Adani M, Coppini G, Fratianni C, Oddo P, et al. (2015)

Mediterranean Sea large-scale low-frequency ocean variability and water mass formation

rates from 1987 to 2007: A retrospective analysis. Progress in Oceanography 132: 318-332: doi:10.1016/j.pocean.2013.11.003.

Piva A, Asioli a., Trincardi F, Schneider RR and Vigliotti L (2008) Late-Holocene climate variability in the Adriatic Sea (Central Mediterranean). The Holocene 18(1): 153-167: doi:10.1177/0959683607085606. 
689 Rodrigo-Gámiz M, Martínez-Ruiz F, Jiménez-Espejo FJ, Gallego-Torres D, Nieto-Moreno V, 690 Romero O, et al. (2011) Impact of climate variability in the western Mediterranean during the 691 last 20,000 years: Oceanic and atmospheric responses. Quaternary Science Reviews. Elsevier 692 Ltd 30(15-16): 2018-2034: doi:10.1016/j.quascirev.2011.05.011.

693 Rohling E, Mayewski P, Abu-Zied R, Casford J and Hayes A (2002) Holocene atmosphere694 ocean interactions: Records from Greenland and the Aegean sea. Climate Dynamics 18(7): 695 587-594: doi:10.1007/s00382-001-0194-8.

696 Rohling EJ, Marino G and Grant KM (2015) Mediterranean climate and oceanography, and 697 the periodic development of anoxic events (sapropels). Earth-Science Reviews 143: 698 doi:10.1016/j.earscirev.2015.01.008.

699 Sangiorgi F, Capotondi L, Combourieu Nebout N, Vigliotti L, Brinkhuis H, Giunta S, et al. 700 (2003) Holocene seasonal sea-surface temperature variations in the southern Adriatic Sea 701 inferred from a multiproxy approach. Journal of Quaternary Science: doi:10.1002/jqs.782. Sbaffi L, Wezel FC, Kallel N, Paterne M, Cacho I, Ziveri P, et al. (2001) Response of the 703 pelagic environment to palaeoclimatic changes in the central Mediterranean Sea during the Late Quaternary. Marine Geology 178(1-4): 39-62: doi:10.1016/S0025-3227(01)00185-2. Schwab C, Kinkel H, Weinelt M and Repschlger J (2012) Coccolithophore paleoproductivity and ecology response to deglacial and Holocene changes in the Azores Current System. Paleoceanography: doi:10.1029/2012PA002281.

708 Sellschopp J and Álvarez A (2003) Dense low-salinity outflow from the Adriatic Sea under 709 mild (2001) and strong (1999) winter conditions. Journal of Geophysical Research. John 710 Wiley \& Sons, Ltd 108(C9): 8104: doi:10.1029/2002JC001562.

711 Shabrang L, Menna M, Pizzi C, Lavigne H, Civitarese G and Gačić M (2016) Long-term 712 variability of the southern Adriatic circulation in relation to North Atlantic Oscillation. Ocean 
713

714

715

716

717

718

719

720

721

722

723

724

Science 12(1): 233-241: doi:10.5194/os-12-233-2016.

Siani G, Magny M, Paterne M, Debret M and Fontugne M (2013) Paleohydrology

reconstruction and Holocene climate variability in the South Adriatic Sea. Climate of the Past 9(1): 499-515: doi:10.5194/cp-9-499-2013.

Sicre M-A, Bard E, Ezat U and Rostek F (2002) Alkenone distributions in the North Atlantic and Nordic sea surface waters. Geochemistry, Geophysics, Geosystems 3(2): 1 of 13-13 13: doi:10.1029/2001GC000159.

Sicre M-A, Jalali B, Martrat B, Schmidt S, Bassetti M-A and Kallel N (2016) Sea surface temperature variability in the North Western Mediterranean Sea (Gulf of Lion) during the Common Era. Earth and Planetary Science Letters. Elsevier 456: 124-133: doi:10.1016/J.EPSL.2016.09.032.

Sierro FJ, Hodell D a., Curtis JH, Flores J a., Reguera I, Colmenero-Hidalgo E, et al. (2005) Impact of iceberg melting on Mediterranean thermohaline circulation during Heinrich events. Paleoceanography 20(2): 1-13: doi:10.1029/2004PA001051.

Simoncelli S, Masina S, Axell L, Liu Y, Salon S, Cossarini G, et al. (2016) MyOcean regional reanalyses: overview of reanalyses systems and main results. Mercator Ocean Journal 43.

Skampa E, Triantaphyllou M V., Dimiza MD, Gogou A, Malinverno E, Stavrakakis S, et al. (2019) Coupling plankton - sediment trap - surface sediment coccolithophore regime in the North Aegean Sea (NE Mediterranean). Marine Micropaleontology: doi:10.1016/j.marmicro.2019.03.001.

Skejić S, Arapov J, Kovačević V, Bužančić M, Bensi M, Giani M, et al. (2018)

Coccolithophore diversity in open waters of the middle Adriatic Sea in pre- and post-winter periods. Marine Micropaleontology: doi:10.1016/j.marmicro.2018.07.006.

Sprovieri R, Di Stefano E, Incarbona A and Gargano ME (2003) A high-resolution record of the last deglaciation in the Sicily Channel based on foraminifera and calcareous nannofossil quantitative distribution. Palaeogeography, Palaeoclimatology, Palaeoecology 202(1-2): 
740 Sprovieri R, Di Stefano E, Incarbona A and Oppo DW (2006) Suborbital climate variability

741 during Marine Isotopic Stage 5 in the central Mediterranean basin: evidence from calcareous

742 plankton record. Quaternary Science Reviews 25(17-18): 2332-2342:

743 doi:10.1016/j.quascirev.2006.01.035.

744 Theocharis A, Krokos G, Velaoras D and Korres G (2014) An Internal Mechanism Driving

745 the Alternation of the Eastern Mediterranean Dense/Deep Water Sources. American

746 Geophysical Union (AGU), 113-137: doi:10.1002/9781118847572.ch8.

747 Totti C, Civitarese G, Acri F, Barletta D, Candelari G, Paschini E, et al. (2000) Seasonal

748 variability of phytoplankton populations in the middle Adriatic sub-basin. Journal of Plankton

749 Research. Oxford University Press 22(9): 1735-1756: doi:10.1093/plankt/22.9.1735.

750 Triantaphyllou M V., Dimiza MD, Krasakopoulou E, Malinverno E, Lianou V and

751 Souvermezoglou E (2010) Seasonal variation in Emiliania huxleyi coccolith morphology and

752 calcification in the Aegean Sea (Eastern Mediterranean). Geobios 43(1): 99-110:

753 doi:10.1016/j.geobios.2009.09.002.

754 Triantaphyllou M V., Gogou A, Dimiza MD, Kostopoulou S, Parinos C, Roussakis G, et al.

755 (2016a) Holocene Climatic Optimum centennial-scale paleoceanography in the NE Aegean

756 (Mediterranean Sea). Geo-Marine Letters 36(1): 51-66: doi:10.1007/s00367-015-0426-2.

757 Triantaphyllou M V., Karatsolis B, Dimiza MD, Malinverno E, Cerino F, Psarra S, et al.

758 (2016b) Coccolithophore combination coccospheres from the NE Mediterranean Sea: new

759 evidence and taxonomic revisions. Micropaleontology 61(6): 457-472.

760 Triantaphyllou M V., Ziveri P, Gogou A, Marino G, Lykousis V, Bouloubassi I, et al. (2009)

761 Late Glacial-Holocene climate variability at the south-eastern margin of the Aegean Sea.

762 Marine Geology 266(1-4): 182-197: doi:10.1016/j.margeo.2009.08.005.

763 Trouet V, Esper J, Graham NE, Baker A, Scourse JD and Frank DC (2009) Persistent positive

764 North Atlantic oscillation mode dominated the Medieval Climate Anomaly. Science (New 
766 Vallefuoco M, Lirer F, Ferraro L, Pelosi N, Capotondi L, Sprovieri M, et al. (2012) Climatic

767 variability and anthropogenic signatures in the Gulf of Salerno (southern-eastern Tyrrhenian

768 Sea) during the last half millennium. Rendiconti Lincei 23(1): 13-23: doi:10.1007/s12210-

769 011-0154-0.

770 Vilibić I, Matijević S, Šepić J and Kušpilić G (2012) Changes in the Adriatic oceanographic

771 properties induced by the Eastern Mediterranean Transient. Biogeosciences: doi:10.5194/bg-

772 9-2085-2012.

773 Wirth SB, Glur L, Gilli A and Anselmetti FS (2013) Holocene flood frequency across the

774 Central Alps - solar forcing and evidence for variations in North Atlantic atmospheric

775 circulation. Quaternary Science Reviews 80: 112-128: doi:10.1016/j.quascirev.2013.09.002.

776 Ziveri P, Baumann KH, Böckel B, Bollmann J and Young JR (2004) Biogeography of

777 selected Holocene coccoliths in the Atlantic Ocean. Coccolithophores: from molecular

778 process to global impact, 403-428: doi:10.1007/978-3-662-06278-4_15.

779

780 